\title{
Colonialism and Education: The Challenges for Sustainable Development in Nigeria
}

\author{
Enwo-Irem, Immaculata Nnenna
}

\author{
Department of History, \\ Ebonyi State College of Education, \\ Ikwo-Ebonyi State, Nigeria
}

\section{Doi:10.59017mjss.2013.v4n5p163}

\begin{abstract}
This paper examined colonialism and education; the challenges for sustainable development in Nigeria. It reveals that during the colonial period, that the type of education introduced did not meet the aspirations of the people. It was manly for the electives. The colonial powers only need those reliable natives they could hand over power to and not the people who could actually manage the economy and the resources in the country. The policy of the colonial education was not geared toward achieving sustainable development in the country; rather it was to plant the seed of discord between those who acquired it and those who had not. This paper concluded that in as much as it did not aim at under mining the advantages of colonial western education in Nigeria, but western type of education policy and curriculum did not consider development of the native a major issue. To over come that issue however, the paper suggested ways forward.
\end{abstract}

\section{Introduction}

There are three fundamentally distinct education system in Nigeria today which include the Indigenous/Traditional/Informal Education, Islamic Education and Western. Before the introduction of formal education in what came to be Nigeria it was informal, traditional or preliterate Education. This system of education still exists and remains the only education for vast numbers of Nigeria peoples ever through it now exists side by side with the formal western or Islamic education. For all the nations and ethnic groups that make up Nigeria, the purpose of traditional education was, and is, to make a person a useful member of his society.

Before the introduction of colonial rule, the emphasis in traditional education was group solidarity; the need for every individual to be an accepted member of the society who believed in the rules, regulations, mores and practices of the group and willing to die for the group should the need arise Ocho (2003).

Quranic or Islamic type of education is the type of education that came into Nigeria through Islamic religion. The philosophy of Islamic education is centered on enabling individuals who acquire it become the kind of people an Islamic society conceives. As a duty, Islamic education taught the Quran, Arabic alphabets and ability to copy texts in Arabic and texts needed in the Islamic daily prayers. Later, grammar, syntax, asthmatic, algebra, logic, rhetoric, jurisprudence and theology were included in the Islamic education. This type 0 education as available records show, came as a result of the Islamization of the Northern part of Nigeria. By the $13^{\text {th }}$ Century, Kamam Bomo had become a centre for Islamic learning Fafunwa (1974). Islamic education started in and is still prevalent in Northern Nigeria. But presently it has spread to Western and Eastern Nigeria, albert, at minimal significance. The indigenous and Islamic types of education, though were taught informally, there were taught with out reservation.

The Western -styled education is the latest education system in Nigeria. This system of education taught the local people European culture and focused on examination. This educational tradition, began seriously in Nigeria with the arrival of the Wesleyan Christian Missionaries at Badagry in 1842. Between 1842 
and 1914, about ten different Christian mission had arrived and begun intensive missionary and education work in Nigeria. Although literary education in the 4Rs (reading, writing, arithmetic and religion was predominant, this new missionary education prepared the recipients for new opportunities as teachers, church evangelists or pastors, clerks and interpreters. The curriculum of this type of education was not geared towards achieving the technological advancement and economic development needed in Nigeria.

\section{Concept of Education}

Education is a gradual process of acquiring skills and habits that make one fit into his society and thereby become responsible to himself and the entire community Fafunwa (1974) Tijani and Musa in Fagbemi (2009) Opines that education turns the individual into a well, adjusted, modest, refined, meticulous responsible and well organized person. It is therefore the duty of the every responsible government any where is the world to provide Qualitative education for its citizenry.

\section{Colonialism or Colonial Rule}

Colonialism or colonial rule simply mean the annexation and subsequent domination of one country by another. In the case of African, Nigeria inclusive, all the colonial powers came from Western Europe, that is, Britain, France, Germany, Portugal, Italy and Belgium. Domination here means total control of political, economic and social affairs of the colony as in Nigeria by the colonizing power. It has been said that economic motives were the main reason for the Europe colonization of Nigeria.

\section{Sustainable Development}

Sustainable development entails the maintenance of a steady growth improvement in the people ability and capacity for greater creativity, discipline, responsibility and overall material well being relatively free from bondage and the elimination of exploration Nwanekwe in Oboke, Nkwede \& Enwo (2011).

All these are guaranteed with an existing machinery of government and productive Institution to meet the rising demand of the people.

Abah in Okolie (2005) gave broader and more encompassing definitions; sustainable development is defined as development that meets the needs of the present without even compromising the ability of future generations to meet their own need.

Sustainable development entails long-term plan. It occurs in a society where the attainment and qualitative realization of a state of affairs is characterized by adequate and equitable distribution of social services, qualitative human happiness and welfare and mastery of his environment as well as free individual participation in the affairs of the state. Oboke, Nkwede \& Enwo (2011).

\section{Colonial Education in Nigeria}

The Colonial Government came to Nigeria in about 1851 but did not involved herself in the provision of Western Education until 1877. The Western Education was connected with the Christian Missionaries. Between 1842 and 1914, about ten different Christian missions had arrived and begun intensive missionary and education work in Nigeria. Schools were built and the missions struggled for pupils/members such that there was a proliferation of primary schools established by different missions.

According to Orji (1992), it was in 1877 that the Colonial Government gave a grant of $£ 200.00$ (Two Hundred Pounds) each to the three major missionaries operating in Lagos, as a recognition of their good work. This act became the first known government involvement in western education in Nigeria. 
In 1882, the Colonial Government enacted the first education ordinances for the Colonial Government to control education in Nigeria. The twin forces of missionary activity and western education reinforced the divisive tendencies in Africa Nigeria inclusive. The emphasis ungroup solidarity was weakened by the growth of Christianity, information and technology and other World Religions and by the inclusion of vast and different people into one Nigerian state.

The influence of British education gave rise to what Uche (1980) referred to as the "marginal man". "A sociological term meaning a minority in a society who share the preferred culture to a significant degree, but are blocked from full participation". The Colonial Education Policy resulted in cultural, economic and social division in society between those who went to school and those who did not.

\section{March to Independence}

The phase of world-wide depression, which began during the second World War from the political perspective ignited the clamour by Nigeria Nationalist' Movement for self government and educational relevance which gained momentum in 1944. Thus from 1944 to Independence in 1960 was a period of self determination and educational expansion in Nigeria. This development formed the basis for the promulgation of the 1948 Education ordinance, which decentralized educational administration in the country. The Colonial Government additionally reviewed its ten years educational plan for Nigeria, and appointed a director of education as well as mapped out a clear cut procedure for assessing grants-in -aid by mission schools Fagbunmi in Mkpa (2000). At the time the educational system in the southern part of Nigeria comprised a four year junior primary education, which was followed by a four year senior primary education and a six year secondary education.

In the northern part of Nigeria, the school system comprise of four year of junior primary schooling, three - years middle school and secondary classes 1 to 6 in some places, middle school classes 1 to 6 . The educational system was not uniform throughout the country. These differences notwithstanding the 1948 Educational Ordinance was a mile stone in British colonial educational policy in Nigeria because it was the first educational legislation that covered the whole country. Fafunwa (2004).

\section{Colonial Western Education and Sustainable Development in Nigeria}

As pointed out by Obiwulu (2010), "Education is very important and should be acquired by one for one's personal good, the good of the family and the State". Proper education as we know is very important for both personal and national development. The type of education being referred to in his part of this piece is the western type of education which was introduced by colonialism. It is a truism that while western education stated in Nigeria in 1842 as mentioned earlier, year 1900 marked the early beginning of colonialism. The earlier arrival of western education was just a stage as the colonization process.

Western Education as introduced in Nigeria by the colonial administrators was only aimed at pacifying the area. It was just for the elites. This, of course is supported by Ernest Gelner's theory that domination and oppression is disseminated through educational means.

The motive behind the introduction of Western education by the colonialists was not really aimed at enhancing the development of the colony they termed Nigeria. The colonial agents had series of problems in administrating the people and in the exploitation of natural resources in the land. Some of the problems were the problem of acceptance of the colonial agents in some parts of the country, and that of language barrier in areas where the local people appeared to have accepted the colonial agents. So they decided to use education to tackle some of the problems.

Ukeje (1978:2) has defined education as: 
A process by which people are acclimatized to the culture into which they are born in order that they may advance. It in the simplest language, it is the process by which people are prepared to live effectively and efficiently in their environment.

This definition appeals to us because its emphases are one people getting acquainted to their culture and advancing it and preparing people to live together effectively and efficiently. The type of education introduced by the colonial administration, instead of acclimatizing the different Nigeria peoples to their cultures and preparing them to advancing them, brought in a new culture which complexly opposed their own. In the worlds of Nwabughuogu (2009);

Western Education, itself a product of missionary activity and colonial government reinforced the divisive tendencies in African societies. There were noticeable divisions between those who had acquired western education (usually called the educated) and those who had not (called the illiterates). The educated often treated illiterates as inferior and this created enmities between the two. Even among the educated, there were still discrimination centered on the type of school attended, the level of education attained, the type of course pursued and the quality of certificates obtained ...

In fact, colonial legacies like boundary disputes, urbanization, missionary activities and western education have not provided and environment for sustainable development in Nigeria. This type of Education was not only aimed at solving the problem of language barrier which posed very serious challenge to the colonial administration, this type of education introduced was aimed at producing reliable natives to occupy posts of responsibility which were at the time filled by subordinate Europeans at a great cost. The British education policy did not address the aspirations of the people.

Contrary to the colonial expectation, the elite class produced by their type of education discovered that the colonial policies and programmes were never meant to develop the local people, so they began the clamour for change and the agitation for the own independence. Colonial western education which was aimed at not only producing a small group of clerks artisans and progressive capitalist farmers but also at having socio-political control over the local people later became a problem of its own to the colonialists.

As a result of this, in a place Benin, this education was limited in standard. In fact, colonial western education had limited goals to achieve. Sir Raph More in a letter he sent to Rev. J. Buchaman in Benin said;

I am of the opinion that the education necessary to enable the native on the completion of same (education) to take their place as useful members of the community need not necessarily include the secondary course (NAI,1901).

Colonial western education because it was not aimed at sustainable development, had limitations placed on the standard and scope. For example the missionaries targeted the lower classes in society and converted them. The new converts thus acquired new status and in many societies they become more importance than the traditional authorities. This reversal of authority led to conflicts in many societies. The colonial education policy resulted in cultural, economic and social divisions in society between those who went to school and those who did not. The British authorities were hostile to the over-rapid expansion of academic education. For example Lord Lugard was said to have commented that missionary expansion in southern Nigeria "seems to have produced discontent impatience of any control and an unjust assumption of self important in the individual". This means that the main reason behind British involvement in Education was not their desire to expand educational facilities for Nigerians as might be read in their policy statements. According to Uche (1984) for example, it was their desire to restrict the expansion schooling, particularly of academic secondary schooling, which was found fit to be inappropriate to African needs.

Not hiding his stands against the establishment of central school for secondary education in Benin More went further to say that: 
The aping of the European destroy the independence of character and initiative of the native of these territories and certainly during the period of their education, I consider it infinitely preferable to keep the clothed in some suitable native garbs with a view of maintaining their distinctive native character (Bewley, 22, Dec, 1931).

Referring to the last part of Ukeje's definition mentioned above, education is the process by which people are prepared to live effectively and efficiently in their environment, but the Colonial administration adopted the policy of divide and rule. This divide and rule policy was nothing rather than in sighting the people of the colony against one another knowing fully well that no meaningful development will strive in crises ridden environment, the colonial agents made some part of the country to believe that they were born to rule while others were born to serve.

However, as the colonial administrators were leaving Nigeria, they knew that Nigeria would be faced with the problem of development in the country since colonial education policy did not meet the aspiration of the people hence neo-colonialism.

\section{Conclusion}

The argument of this paper remains that colonial western - education was never meant for sustainable development in Nigeria, else, there would not had been limitations on the standard and scope of education at the time of colonialism. There was no functional technology bases education to sustain the economy the colonial agents were leaving behind and this up till this present time still had a lot of implications for planning in Nigeria.

Colonial Western Education was only aimed as sustainable colonial exploitation of the colony (Nigeria). Colonial agents did produce, through their western type of education the situational condition for development in Nigeria.

This paper is not aimed at undermining the advantages of colonial western education in Nigeria, of course, we will for ever remain grateful to the colonial agents for introducing a process of educational change in the country and still call to mind, seriously, the fact that development which is the major motive of any type of education was not part of colonial administrators agenda in Nigeria.

For many years after the British had come and gone, our education system and general development are in quagmire, this is no doubt part of our colonial hang-over or legacies.

\section{Way Forward}

* For us to overcome this part of colonial legacy, both the government and the general populace must be involved.

* Our attitude toward education must change the issue of education for all must be drooped because everybody must not go to school, in stead of shouting education for all producing quantitative population, let us drop it and produce qualitative population no matter how few.

* Nigeria should imitate China by adopting close door policy and sending Nigerians out for the sole aim of learning the technology of the outside world and returning to the country to practice what they would learn.

\section{References}


Bewley, B (22 Dec., 1931), Resident (Bp) to District Officer, NA.I, Bp 78/27.

Fafunwa, A.B. (1974) History of Education in Nigeria. London: George, Allen and Union Ltd

Hauma, I. Education Policy in Nigeria from the colonial Era to the post independence period Italian Journal of Sociology of Education. Vol. 1. 2012181.

Mkpa, A. M The Igbo and the Human Right Situation in Nigeria since 1960: The Education perspective in Afigbo, A.E (2000) The Tears of A Nation And People: The Igbo And Human Right Situation in Nigeria A Symposlum.

NAI CSO 1/13 vol. 14, Dispatch No.160 enclosure, Moor to Rev. J.B. Buchaman, 15 June 1901 lbid.

Nwabughuogu, A. I. (2009) Problems of National Building in Africa. Okigwe, FASMEN Communication. P. 33 - 34.

Obiwulu, A (2010) "Education As Solution to the African Problematique of Crises" in UNZIK. Journal of Arts And Humanities, Vol. II No. 2.

Ocho, L.O. (2003) Educational Policy making implementation and Analysis. Enugu. New Generation Books P. 73.

Oboke, Nkwede \& Enwo, "Politics of Resource Control in Nigeria Federalism and Sustainable Development". In International Journal of Political Science and Administration, Vol.3, No. 1, 2011 P. 91 Nigeria: Blackwell Educational Books.

Orji, A.S. (1992) A Historical Approach to foundation of Education. Owerri, Vemac Publishers P 116 - 117.

"The theory of E. Gellner Revisited Retrieved from en.wikipedia.org/wiki/Ernest Gellner on 15/8/2012

Uche, U. W. (1984) Sociology of Nigeria Education for Universities and Colleges in Nigeria. Owerri: CAJEC Publications. P.11.

Ukeje, B.O (1978) Education for Social Reconstruction Hong Kong, Macmillan Education Press. 